\title{
The Green Revolution: Inducement and Distribution
}

\author{
YUJIRO HAYAMI and VERNON W. RUTTAN*
}

The development and diffusion of modern varieties of rice and wheat in Asia were induced by changing resource endowments. More productive biological and chemical technologies capable of offsetting the effects of population growth are a necessary condition for simultaneous achievement of growth and equity. The new income streams generated by technical change have become a powerful source of demand for institutional change. But rapid growth in rural incomes is also dependent on growth of demand for labour in the non-agricultural sectors.

The introduction of modern biological and chemical technology into Asian agriculture has been criticised and defended from a variety of scientific, populist and ideological viewpoints. In this paper we attempt to throw some light on the historical forces that have given rise to the new 'seed-fertilizer' or 'green revolution' technology. We also attempt to assess the empirical evidence that has become available over the last several decades on the green revolution controversies.

\section{AN INDUCED TECHNICAL CHANGE PERSPECTIVE}

Over the last two decades advances in economic theory and the accumulation of empirical evidence have tended to confirm that the rate and direction of technical change can be interpreted as largely endogenous to the economic system - as induced by differences or changes in the conditions of factor supply and product demand. ${ }^{1}$ Attempts to develop a theory of agricultural development in which changes in agricultural technology can be treated as endogenous to the development process start with a recognition that there are multiple paths of change in agricultural technology available to a society.

*Yujiro, Hayami is Professor in the Department of Economics, Tokyo Metropolitan University. Vernon W. Ruttan is Professor in the Department of Agricultural and Applied Economics and in the Department of Economics, University of Minnesota. The paper draws on material from their forthcoming book, Agricultural Development: A Global Perspective, (Baltimore: The Johns Hopkins University Press), in press.

\footnotetext{
${ }^{1}$ For a review of this literature, see Binswanger, Ruttan et al. [9, pp. 13-43 \& 91-127].
} 
This means that the constraints imposed on agricultural development by an inelastic supply of land may be offset by advances in biological (or biological and chemical) technology. The constraints imposed by an inelastic supply of labour may be offset by advances in mechanical technology. The ability of a country to achieve rapid growth in agricultural productivity and output depends importantly on its ability to make an efficient choice among alternative paths of technical change. Failure to choose a path which effectively loosens the constraints on growth imposed by resource endowments can depress the whole process of agricultural and economic development. The ability to make the efficient technology choice depends critically on investments in human capital needed for development and adaptation of new technologies and, also, on efforts to transform institutions if the full productive potential of the new technologies is to be realized.

Technical change is not, of course, wholly induced by economic forces. In addition to the effects of resource endowments and growth in demand, technical change reflects the impact of the autonomous advance of science and technology. Progress in general science which lowers the 'cost' of technical and institutional innovations may have influences on technical change that are unrelated to changes in factor proportions and product demand. But even in these cases, the rate of adoption and the impact on productivity of autonomous or exogenous changes in technology will be strongly influenced by the conditions of resource supply and product demand, as these forces are reflected in factor and product markets.

The new tropical grain production technology can be viewed as a result of agricultural technology transfer between different ecological zones through the transfer of material inputs, the transfer of scientific knowledge and the development of local agricultural research capacity. This process has also involved institutional innovations designed to promote the transfer of the capacity to invent, disseminate and use the new biological technology. In this section, we elaborate on the induced innovation model to illustrate the role of economic forces in inducing international and national agencies to change development policies and to initiate the institutional innovations that have led to the creation of a new potential for grain production in the tropics. ${ }^{2}$

The modern high-yielding varieties (MVs) of rice recently developed in tropical Asia, similar to the 'proto-type high-yielding varieties' in Japan, are distinguished by high fertilizer responsiveness. Their fertilizer-responsive capacity is fully realized only when they are accompanied by better husbandry practices (e.g. weed and insect control) and by adequate water control. Traditional varieties had long survived with

${ }^{2}$ This section represents an updated version of Hayami [28]. The material discussed in this section is presented in greater detail in Kawagoe and Hayami [35]. little fertilization under unfavourable environmental conditions, including a precarious water supply and rampant weeds. Under such conditions the traditional varieties represented an optimum technology. ${ }^{3}$

The fertilizer response curves for the traditional varieties and the MVs are typically drawn as $u_{0}$ and $u_{1}$, respectively, in Figure 1a. We assume a 'metaproduction function' (U) which is the envelope of many such response curves, each representing a variety characterized by a different degree of fertilizer responsiveness; $a_{0}$ and $m_{0}$, $a_{1}$ and $m_{1}$, and UAC and UMC in Figure $1 b$ are the average and marginal product curves corresponding, respectively, to $\mathrm{u}_{0}, \mathrm{u}_{1}$, and $\mathrm{U}, \mathrm{u}_{0}$ represents an optimum (profit-maximizing) variety for the fertilizer-rice price ratio, $\mathrm{p}_{0}$; and $\mathrm{u}_{1}$ represents an optimum for $p_{1}$. However, even if the fertilizer-rice price ratio declines from $p_{0}$ to $p_{1}$ individual farmers connot move from A (or D) to B (or E), and will be trapped at C (or F) unless $u_{1}$ becomes available. C represents an equilibrium for a response curve $\left(u_{0}\right)$ that is actually available for farmers, but a disequilibrium in terms of potential alternatives described by the metaproduction function $\left(u_{1}\right)$. It is hypothesized that the development of a new variety $\left(u_{1}\right)$ is undertaken when the benefit of adjustment from C (or F) to B (or E) exceeds the cost of development of $u_{1}$. This is an oversimplified picture. The location and shape of the fertilizer response curve depends on the conditions of water control and husbandry practices. If water supply and control are inadequate, the MVs would fail to show the fertilizer-responsive character. On the other hand, it is quite possible that in the paddy fields having good irrigation and drainage facilities the MVs produce higher yields than the traditional varieties, even at the zero level of artificial fertilization. In such fields, significant amounts of plant nutrients are supplied from the efficient decomposition of organic materials and from nutrients carried in by irrigation water. Yield response to fertilizer is also dependent on effective weed control, because short-stalked MVs are more subject to competition for sunlight from vigorous growth of weeds encouraged by the high level of fertilization. Application of herbicides and weed-preventing practices, e.g. checkrow planting, become of crucial importance in accurate measurement of the fertilizer response relationships. (We again emphasize that in this formulation the fertilizer input per hectare should be regarded as an index representing the level of the package of inputs complementary to fertilizer in realizing the yield potential of MVs.)

Adjustments along the metaproduction function involve time and costs. The development of fertilizer-responsive MVs requires investment in research. Better husbandry practices must be developed and learned. Complementary investment in irrigation and drainage may be required to secure adequate control of water. It takes

${ }^{3}$ See Jennings [32]. The Jennings article represents the classic statement of the new cropbreeding strategy focusing on models of biologically efficient plant types. See also Chang [11]
and Swaminathan [61]. 


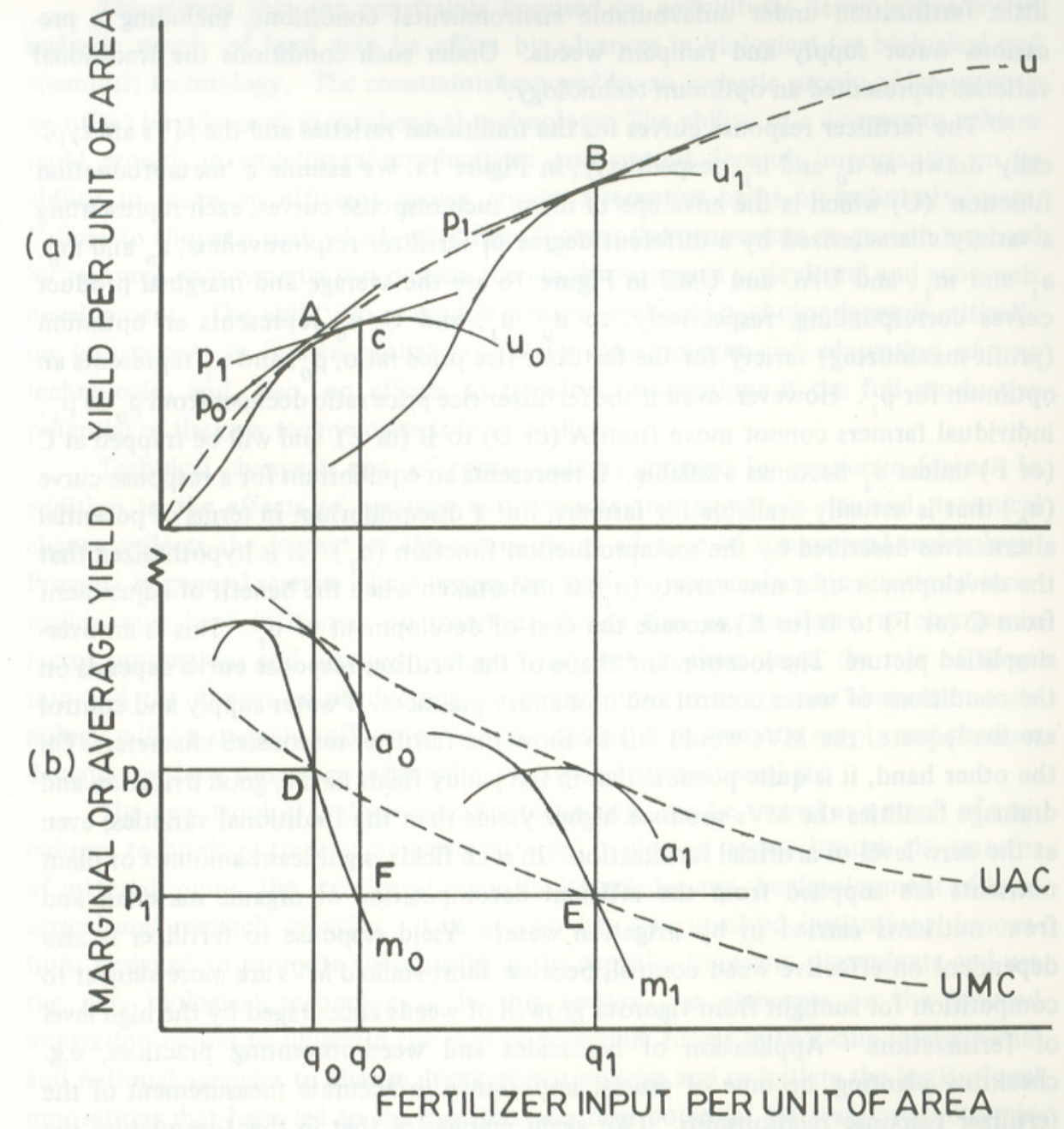

Figure 1. Hypothetical Process of the Induced Development of a Modern Highyielding Variety of Rice

Source: Yujiro Hayami [28] time to reorient the efforts of public agencies in such directions in response to price changes. It is particularly costly and time-consuming to build adequate institutions and competent research staff.

These processes may be inferred from Table 1, which compares for Japan and other selected countries in Asia the price of fertilizers relative to the price of rice and rice yield per hectare of paddy area planted. The data in the table indicate: (a) that the higher rice yield per hectare in Japan than in Southeast Asian countries was associated with a considerably lower price of fertilizer relative to the price of rice; (b) that there was an inverse association between the rice yield per hectare and the fertilizer-rice price ratio in the Japanese time-series data; (c) that the substantial decline in the fertilizer-rice price ratios from $1955-57$ to $1963-65$ in other Asian countries was associated with only small gains in rice yield per hectare; (d) that the fertilizer-rice price ratios in the South and Southeast Asian countries in 1963-65, the years immediately prior to the 'green revolution', were much more favourable than those which prevailed in Japan at the beginning of this century and earlier; and (e) that significant gains in rice yield per hectare in the South and Southeast Asian countries from 1963-65 to 1975-77 were not associated with further decreases in the fertilizer-rice price ratios.

Table 1

Fertilizer-Rice Price Ratio and Rice Yield per Hectare in Selected Asian Countries, 1955-57, 1963-65, and 1975-77, and in Japan, 1883-1962

\begin{tabular}{lccccc}
\hline Country & $\begin{array}{c}\text { Currency } \\
\text { unit }\end{array}$ & $\begin{array}{c}\text { Price of } \\
\text { fertilizer: } \\
\text { per } \mathrm{m} \text {. ton } \\
\text { of nitrogen }\end{array}$ & $\begin{array}{c}\text { Price of } \\
\text { rice: per } \\
\text { m. ton of } \\
\text { milled rice }\end{array}$ & $\begin{array}{c}\text { Fertilizer- } \\
\text { rice } \\
\text { price ratio }\end{array}$ & $\begin{array}{c}\text { Rice yield } \\
\text { per ha: } \\
\text { m. ton of } \\
\text { paddy }\end{array}$ \\
\hline$(1)$ & $(2)$ & $(3)$ & $(4)$ & $(5)=(3) /(4)$ & $(6)$ \\
\hline
\end{tabular}

Intercountry Comparison

1955-57

1,000 yen

$\begin{array}{rr}4,541 & 1,606 \\ 3,877 & 1,687 \\ 530 & 180 \\ 134 & 343\end{array}$

India

Philippine

Thailand

Japan

peso

U.S.\$.

1,675

1,000 yen

962
393

1963-65

India

Philippines

Thailand

rupee

peso

Japan

U.S.\$.

1,000 yen

1,048

1975-77

India

Philippines

Thailand

rupee

peso

U.S.\$.

$417^{c}$

352
79

79
77

77

4.0
2.7

2.7

1.5

595

595
530

70

99

2.9

2.0
3.3

1.0

1.3

1.1

1.4

4.8

1.5

1.3

Japan ns

d at ; e 1

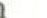

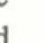
, .

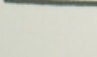

$\begin{array}{rll}1,606 & 2.8 & 1.9 \\ 1,687 & 2.3 & 1.8 \\ 180 & 2.9 & 1.8 \\ 343 & 0.4 & 6.0\end{array}$




\begin{tabular}{ccrrrr}
\hline Japan's Time Series & & & & & \\
$1883-87$ & yen & 450 & 42 & 10.7 & 2.6 \\
$1893-97$ & yen & 670 & 69 & 9.7 & 2.6 \\
$1903-07$ & yen & 815 & 106 & 7.7 & 3.1 \\
$1913-17$ & yen & 803 & 125 & 6.4 & 3.5 \\
$1923-27$ & yen & 1,021 & 277 & 3.7 & 3.6 \\
$1933-37$ & yen & 566 & 208 & 2.7 & 3.8 \\
$1953-57$ & 1,000 yen & 113 & 75 & 1.5 & 4.3 \\
$1963-67$ & 1,000 yen & 100 & 85 & 1.2 & 5.1 \\
$1973-77$ & 1,000 yen & 125 & 305 & 0.4 & 5.8 \\
\hline
\end{tabular}

Source: Intercountry data

FAO: Production Yearbook, Fertilizer Annual Review, and
Fertilizer Year Book.

Data for Japan

Kazushi Ohkawa et al. (ed.), Long-term Economic Statistics of Japan. Vol. 9. Tokyo: Toyokeizaishimposha. 1966. pp. 202-203.

Nobufumi Kayo (ed.). Nihon Nogyo Kisotokei. Tokyo: Norin Suisangyo Seisankojokaigi. 1958. p. 514.

Toyokeizaishimposha. Bukka Yoran. Tokyo. 1967. p. 80.

Institute of Developing Economies. One Hundred Years of Agricultural Statistics in Japan. Tokyo. 1969. p. 136.

Japan. Ministry of Agriculture, Forestry and Fisheries. Norinsho Tokeihyo. Tokyo. (Various issues)

Notes: a Wholesale price at a milled rice basis. Data for Japan are converted from a brown rice basis to a milled rice basis assuming 10 percent processing cost.

${ }^{\mathrm{b}} \mathrm{Data}$ of Japan are converted from a brown rice basis to a paddy basis assuming 0.8 for a conversion factor.

${ }^{\mathrm{c}}$ Price at Sambalpur, Orissa.

It seems reasonable to infer that the considerable differences in the rice yield and the price ratios between Japan and Southeast Asian countries can best be interpreted in terms of the different fertilizer response curves as shown by $u_{0}$ and $u_{1}$ in Figure 1. The consistent rise in the rice yield per hectare, accompanied by the consistent decline in the fertilizer-rice price ratio in the historical experience of Japan, indicates a process of movement along the metaproduction function. The history of the development of Japanese agricultural technology, including the deliberate efforts of veteran farmers to select and propagate superior varieties, the vigorous activities in experiment stations and other research nstitutions, and the remarkable shifts of rice varieties over time, is clearly inconsistent with an assumption of movement along a fixed production response curve $\left(u_{0}\right)$.

When we examine the data for Southeast Asia, some intriguing questions remain unanswered. Why did rice yields per hectare in the Southeast Asian countries increase so slowly prior to the mid-1960s in spite of the substantial decline in the fertilizer-rice price ratio? And, why did rice yields in these countries remain at low levels despite fertilizer-rice price ratios which were more favourable in these countries than in Japan at the beginning of this century? The answer must be sought in the time-lag required to move along the metaproduction function. This time-lag tends to be extremely long in situations characterized by lack of adequate institutions and human capital to generate the flow of new techniques. Apparently, before 1960, the countries in Southeast Asia, even though the fertilizer-rice ratio declined from $\mathrm{p}_{0}$ to $\mathrm{p}_{1}$, could not move from A (or D) to B (or E) in Figure 1 because of a lag in the investment in the experiment station capacity necessary to create a new technology $\left(u_{1}\right)$. They seem to have been trapped at C (or F). On the other hand, movements of their positions from 1963-65 to 1975-77 seem to have been the ones represented by the movement from $\mathrm{C}$ (or F) towards $\mathrm{B}$ (or E).

The dramatic appearance of the MVs after 1965 can be interpreted in this light. The efforts of the International Rice Research Institute, the University of the Philippines College of Agriculture, and the Bureau of Plant Industry in the Philippines, of the Japanese plant breeders in Malaysia under the Colombo Plan, of the Indian Council of Agricultural Research, and of various other national research organizations were designed to develop fertilizer-responsive MVs. By the mid-1960s, a number of varieties satisfying these requirements, including IR-8, C4-63 Malinja, and ADT -27 , were being released to farmers. It now seems clear that these innovations were induced by a potential high pay-off of investment in crop-breeding research, thus permitting the adjustment from C (or F) to B (or E). Indeed, even though the fertilizer price relative to the rice price did not decline further from $1963-65$ to $1975-77$, rice yields per hectare increased significantly as the result of MV development that enabled the movement from inside to the surface of the metaproduction function.

Because the 'proto-type high-yielding varieties' were already in existence in Japan, the United States, and other temperate zone rice-producing countries before the 'green revolution', it was possible to realize major advances in potential productivity from a relatively modest research investment. A critical element in the realization of the high pay-off to investment in research was dependent on a socia decision to invest in research rather than on decisions made by individual firms. The farms operated by Asian producers are, except in the cases of a few export commodities, too small to capture the gains necessary to pay for research investments. It is only when public agencies (or semi-public agencies such as foundations) perceive this opportunity and allocate funds for s". ch research that technological transfer or development becomes feasible.

Declines in the price of fertilizer relative to the price of rice during the 1950 s and 1960 s were the result of increased productivity in the chemical fertilizer industry in the developed countries. These lower costs were initially transmitted to less 
developed countries through international trade and later through the growth of domestic fertilizer production. In most parts of Asia characterized by high population density, the increase in population and food demand has resulted in increasing pressure against land. It seems reasonable to hypothesize that the pay-off of the crop breeding research was enhanced by the capacity of the MVs to facilitate the substitution of an increasingly abundant factor (fertilizer) for an increasingly scarce factor (land). It seems valid to regard the agricultural research which produced the new fertilizer-responsive varieties as a response to a decline in the price of fertilizer relative to the price of land and to the price of rice. In the absence of a decline in the real price of fertilizer, such research might not have been attempted and, even if attempted, the results would have been incompatible with price relationships among factors and products and would have been similar to earlier attempts to introduce mechanization in tropical rice production. Success of research depends on whether it is directed to the generation of a technology compatible with the market prices that reflect product demand and factor endowments of the economy.

\section{TECHNOLOGY, POPULATION PRESSURE AND INCOME DISTRIBUTION}

It seems apparent, from the material reviewed in the previous section, that the development and diffusion of modern varieties (MVs) of rice and wheat in the tropics since the late 1960 s were highly appropriate when evaluated in terms of the resource endowments of the countries in which the new technology was introduced and adopted.

Introduction of the modern seed-fertilizer technology has not, however, been without controversy. Critics have argued that the gains in production have been offset by losses in equity - that the new technology has been both subversive of traditional institutions and regressive in its impact on rural incomes. ${ }^{4}$

In rural communities, the major source of inequality in income distribution is the inequitable distribution of land ownership, which often corresponds to the inequitable distribution of operational holdings. If the share of agricultural income accruing to labour increases, the income position of tenants and agricultural labourers improves relative to landlords and owner-cultivators. The reverse holds if the income share accruing to land increases. Therefore, land-saving and labourusing technological changes that raise the economic return to labour relative to land have the effect of equalizing the income distribution between the landless and the

${ }^{4}$ These concerns were expressed in Wharton [62], Johnston and Cownie [34], Falcon [20], and Palmer [48]. More radical views were expressed in Frankel [22], Cleaver [15], Fatemi [21], Griffin [27], and Lappe and Collins [41]. The impact of the green revolution on income distribution in Pakistan has been vigorously debated. See Khan [36], Chaudhry [13], Khan [37], and Chaudhry [14]. land-owning classes. In contrast, labour-saving and land-using technological changes contribute to greater inequality.

Since the biological-chemical technology is geared to saving land by applying labour and biological-chemical inputs more intensively, its diffusion might be expected to contribute to a more favourable income distribution in rural communities. Nevertheless, the new seed-fertilizer technology has often been blamed for benefiting landlords at the expense of tenants and labourers on the ground that land rents increased while wage rates stayed the same or even declined in many areas where MV and related inputs were introduced. These arguments have often ignored a critical factor coinciding with the MV diffusion - the growing pressure of population on the land.

During the past two decades the labour force engaged in agricultural production in countries in South and Southeast Asia increased at rates of $1.0-2.5$ percent per year [30, pp. 39-40]. Meanwhile, the arable land area has increased at rates of about 1.0 percent or less. The deterioration in the man-land ratio has been even more serious than implied by the data since the cultivation frontier has been expanded largely into marginal, less productive areas. Classical economists like Ricardo predicted that as the cultivation frontier expands onto lower-quality land the marginal return to additional labour input would decline and the cost of food production rise - real-wage rates would decline and rents would rise. If this process had not been partially offset by the adoption of land-saving technology, incomes would have fallen further and a larger portion of agricultural income would have accrued to landlords.

Several highly simplified models are presented in Figure 2 to clarify the effects of technological change and population pressure on wage rates, land rent and factor share. ${ }^{5}$ For the sake of simplicity, let us assume an agricultural production function in which output is produced from labour (L) and land (A). Output may be considered as value added after current inputs are deducted and land as land-cumcapital. The upper diagrams in Figure 2 represent aggregate demand and supply of labour in the market and the lower diagrams the production function (f) that relates output per hectare $(q=Q / A)$ to labour input per hectare of land area $(1=\mathrm{L} / \mathrm{A})$. The shape and the location of $\mathrm{f}$ are determined by 'technology, broadly defined to include land infrastructure such as irrigation and drainage. The classical assumption of decreasing return to labour applied per unit of land is adopted.

Case I represents one polar case in which the labour demand curve (the schedule of marginal products of labour) stays constant at $\mathrm{D}_{0}$, reflecting no progress in technology $\left(f_{0}\right)$ while the labour supply shiris from $S_{0}$ to $S_{1}$ owing to population growth. Corresponding to a change in the market equilibrium point from $\mathrm{A}$ to $\mathrm{B}$,

${ }^{5}$ These are developed more fully in Hayami and Kikuchi [30, pp. 49-52] . 


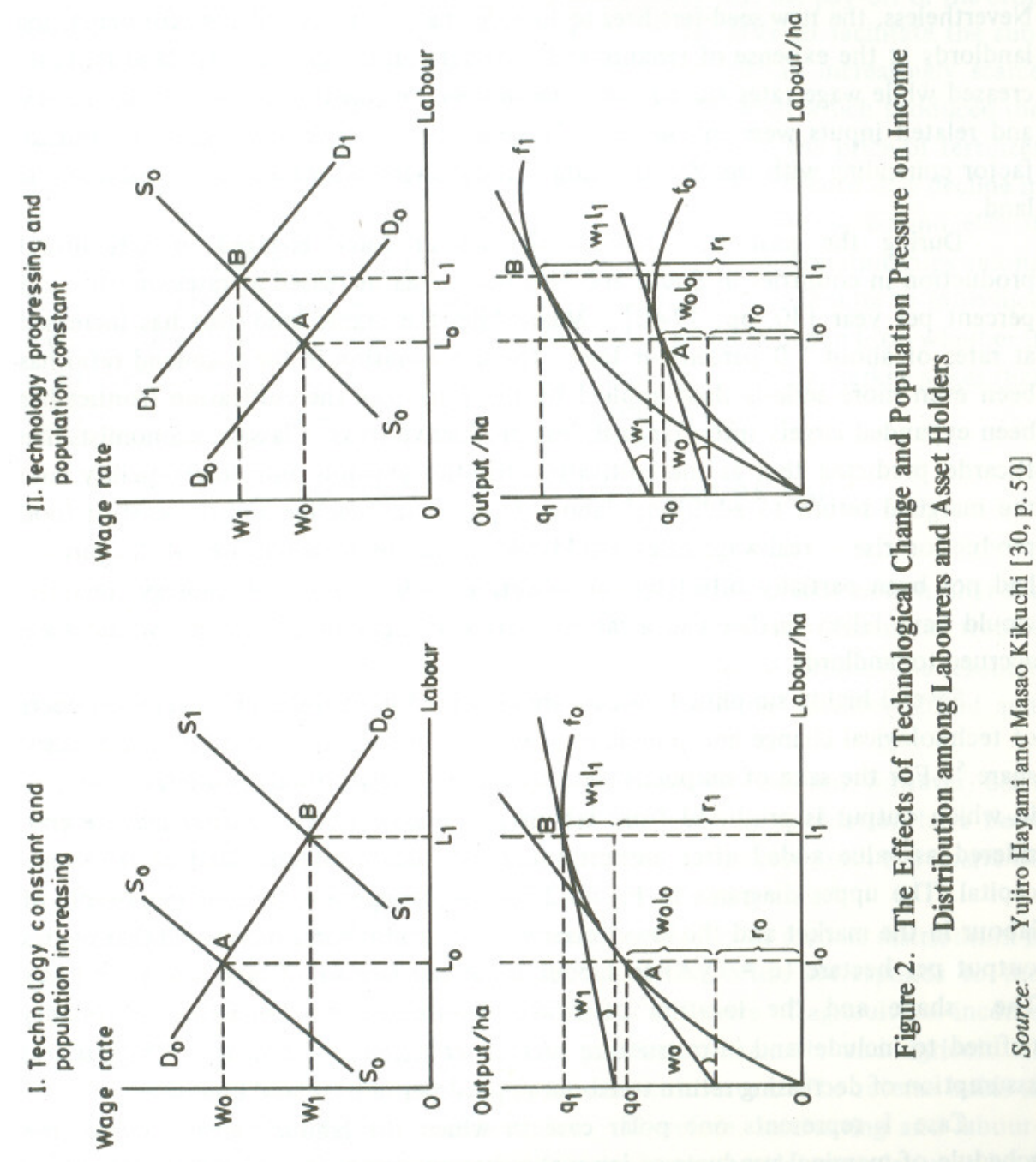

the wage rate declines from $w_{0}\left(0 \mathrm{~W}_{0}\right)$ to $\mathrm{w}_{1}\left(0 \mathrm{~W}_{1}\right)$ and the land rental rate rises from $r_{0}$ to $r_{1}$. If the increased labour is applied to the fixed production function $\left(f_{0}\right)$ at a zone of decreasing return to labour such that the elasticity of substitution of labour for land is less than one (i.e. less than a 1-percent increase in the labourland ratio results from a 1-percent decrease in the wage-rent ratio), the relative income share of labour declines from $\left(\mathrm{w}_{0} \mathrm{l}_{0} / \mathrm{q}_{0}\right)$ to $\left(\mathrm{w}_{1} \mathrm{l}_{1} / \mathrm{q}_{1}\right)$. If the labour application per hectare continues to increase, a point will eventually be reached beyond which the elasticity of factor substitution becomes so small that labour's income declines absolutely corresponding to any further increase in labour input.

Case II represents another polar case. Let us assume that the labour supply remains constant at $S_{0}$ and the labour demand shifts from $D_{0}$ to $D_{1}$, reflecting the upward shift in the production function from $\mathrm{f}_{0}$ to $\mathrm{f}_{1}$. Corresponding to the change in market equilibrium from $A$ to $B$, the wage rate rises from $w_{0}$ to $w_{1}$ and the absolute income of labour from $\left(\mathrm{w}_{0} \mathrm{l}_{0}\right)$ to $\left(\mathrm{w}_{1} \mathrm{l}_{1}\right)$. Whether the relative income share of labour improves or not depends on the nature of the shift in the production function. The relative share of labour $(\mathrm{w} / \mathrm{q})$ increases if the production function shifts in such a way as to increase the labour-land ratio $(1=\mathrm{L} / \mathrm{A})$ for a constant rent-wage ratio $(\mathrm{r} / \mathrm{w})$ at competitive equilibrium - the "land-saving and labour-using technological change' in the Hicks definition.

In the real world, both the demand for and the supply of labour shift simultaneously. However, in many developing countries the shift in the supply of labour due to rapid population growth has outpaced the shift in demand for labour due to technological progress. The result has been a decline in the real wage rate. In such a situation, the income distribution would become more skewed, because the rate of return to land ( $r$ ) would rise relative to that of labour (w) and an increasing share of income would be captured by the land-owning class.

Simple economics tells us that the income and the level of living of the rural poor in developing countries - landless labourers and tenants whose incomes consist mainly of earnings from their labour - will continue to decline both absolutely and relatively unless some combination of land-saving technical change, growth in demand for agricultural commodities, and non-farm demand for labour results in a more rapid growth in demand for labour than the growth in the supply of labour in rural areas.

This does not imply that every change in technology is beneficial to the poor. There is a type of technological change which reduces labour's income by displacing labour by machinery and herbicides. Such technological change is 'labour-saving' in the Hicksian sense. In terms of the right-hand diagram of Figure 2, labour-saving (and land-using) technological change is represented by a shift in the production function in such a way as to reduce the labour-land ratio $(1=\mathrm{L} / \mathrm{A})$ for a constant rent-wage ratio $(\mathrm{r} / \mathrm{w})$. If a technological change is of the labour-saving type, the 
relative income share of labour $(\mathrm{wl} / \mathrm{q})$ declines. It is theoretically possible for the labour-saving bias to be so strong that the absolute income of labour will decline.

\section{GREEN REVOLUTION CONTROVERSIES ${ }^{6}$}

From the discussion in the previous section it should be clear that the development of biological-chemical technology designed to increase agricultural output per unit of land area is a critical factor in offsetting tendencies towards a worsening of income distribution in the rural sector in response to growing population pressure on land. We identify the MV technology as one such technology. Yet, since the initial introduction, often heralded as the 'green revolution', the MV technology has often been viewed as the source of great inequities in income distribution and as a source of polarization in rural communities.

The critics of the 'green revolution' have argued that the new technology tends to be monopolized by large farmers and landlords who have better access to new information and better financial capacity even though MVs and related inputs are divisible and, hence, applicable to small farms; that small farmers are unable to use MVs efficiently because credit constraint makes it difficult for them to purchase cash inputs such as fertilizers and chemicals; that monopoly of the new technology by large farmers enables them to use their profits to enlarge their operational hold ings by consolidating small farmers' holdings; and that as farm size increases it becomes profitable to purchase large-scale machinery and reduce the cost of labour management. The effect is to reduce employment opportunities and lower wage rates for the growing number of landless workers. ${ }^{7}$

How valid is the suggested sequence? Has the adoption of MV technology, in fact, tended to be dominated by large holders? Does the technology make largescale operations relatively more efficient and profitable? Does the MV technology induce mechanization and reduce employment and earnings? Those are the issues that must be examined with empirical data.

\section{Was MV Technology Monopolized by Large Farmers?}

The available evidence indicates that neither farm size nor tenure has been a serious constraint on the MV adoption. The data on adoption of modern wheat varieties from Pakistan, presented in Table 2, are fairly typical of the data available from other areas where MVs are technically well adapted. Essentially, similar results have been reported for wheat in India, rice in India, Indonesia, Malaysia and the Philippines, and maize in Kenya. ${ }^{8}$

${ }^{6}$ This section draws heavily on Hayami [29], Hayami and Kikuchi [30, pp. 52-59], and Ruttan [52]

${ }^{7}$ See the references in footnote 4

${ }^{8}$ See Sen [53, pp. 32-54], Mangahas et al. [46, pp. 23-43], Mangahas [45], Soejono $[58 ; 59]$, Gerhart [23], and Goldman and Squire [25]. For a more complete review of literature on the income distribution effects of the MV technology in South Asia, see Singh [57]
Table 2

Mexican-type Wheat Acreage as Percentage of all Wheat Acreage, by Size and Tenure of Holdings: 1969-70 post-monsoon season in Lyallpur, Sahiwal, and Sheikhupura Districts, Pakistan

\begin{tabular}{lcccc}
\hline $\begin{array}{c}\text { Number of } \\
\text { Acres in Holding }\end{array}$ & $\begin{array}{c}\text { Owner } \\
\text { Holdings }\end{array}$ & $\begin{array}{c}\text { Owner-cum- } \\
\text { Tenants Holdings }\end{array}$ & $\begin{array}{c}\text { Tenant } \\
\text { Holdings }\end{array}$ & All Holdings \\
\hline Less than 12 $\frac{1}{2}$ & 71.0 & 80.4 & 66.7 & 72.5 \\
$12 \frac{1}{2}$ to 25 & 63.3 & 71.7 & 69.2 & 68.0 \\
25 to 50 & 71.9 & 92.7 & 81.9 & 82.0 \\
50 & 73.2 & 87.3 & 57.3 & 78.6 \\
All sizes & 69.4 & 80.5 & 70.0 & 73.4 \\
\hline
\end{tabular}

Source: K.M. Azam [1, p. 408].

Original source: Government of the Punjab, Planning and Development Department, Statistical Survey Unit, Fertilizer and Mexican Wheat Survey Report (Lahore, 1970) p. 38.

This is not to deny that there are cases in which small farmers lagged significantly behind large farmers in the MV adoption. One such case was found in a rice village in Andhra Pradesh, India, covered by an international project co-ördinated by IRRI to study the changes of rice farming in selected areas of Asia [49]. This village was characterized by extremely skewed farm-size distribution and, for that reason, may be taken as evidence in support of the hypothesis that the introduction of MV technology into a community in which resources are distributed in a highly inequitable manner tends to reinforce the existing inequality.

However, this village case is an exception rather than a norm. It was the only village, of the 36 villages studied by the project, where a significant differential in the MV adoption among farm-size classes was observed. On the average, small farmers adopted the MV technology even more rapidly than large farmers (see upper diagram of Figure 3). The pattern of MV diffusion contrasts sharply with the pattern in the diffusion of tractors in which large farmers achieved a distinctly faster and higher rate of adoption (lower diagram of Figure 3)

\section{Did the MV Technology Make Large Farms More Efficient?}

There is now a large body of evidence that suggests that small farms make more efficient use of available land than large farms. ${ }^{9}$ Small farms apply higher levels of labour input, particularly family labour, per unit of land. And they are generally

${ }^{9}$ The literature on the relationship between farm size and productivity has been reviewed by Berry and Cline [7]. 
Cumulative adoption (\%)
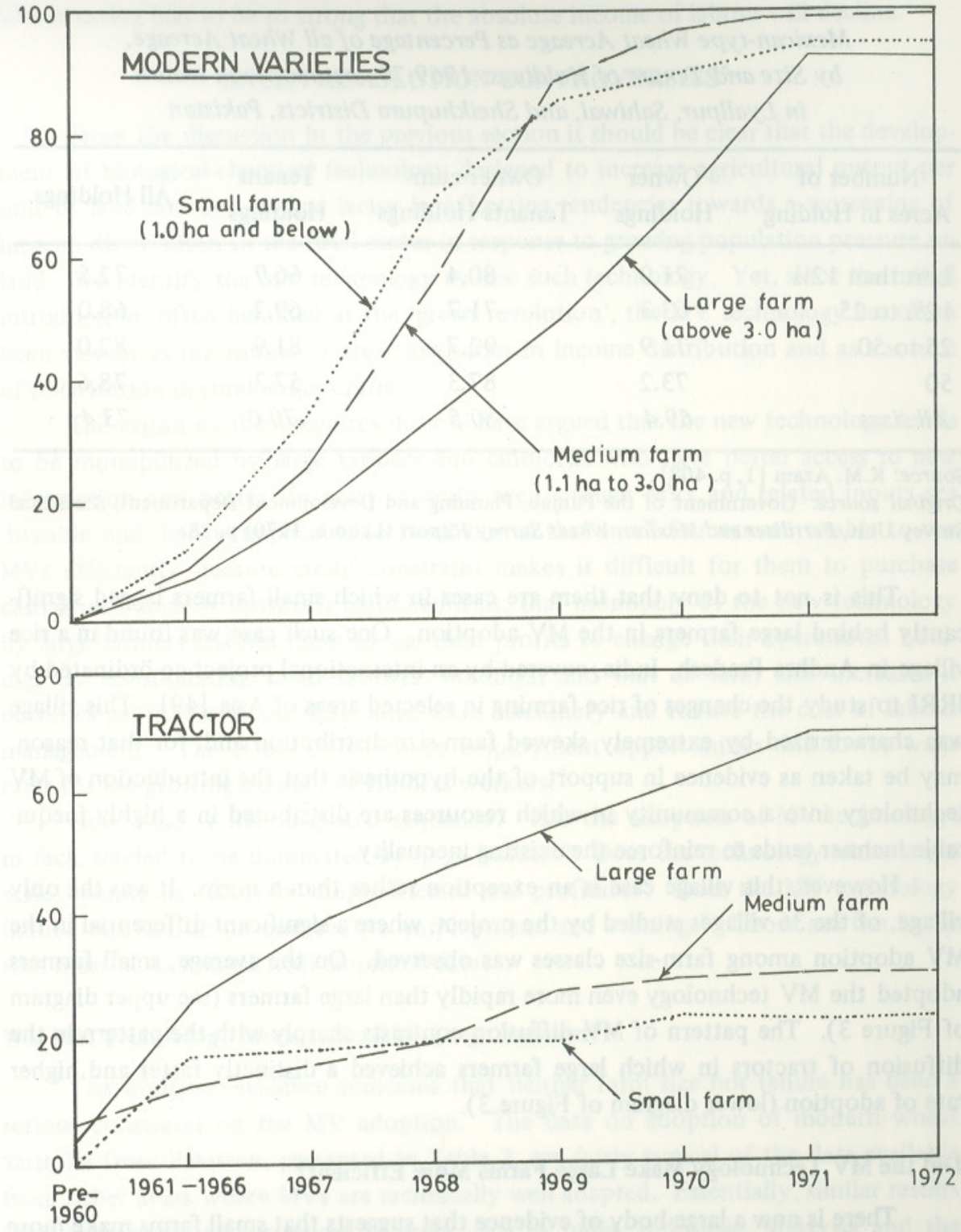

Figure 3. Cumulative Percentage of Farms in Three Size Classes adopting Modern Varieties and Tractor in $\mathbf{3 0}$ Villages in Asia characterized by higher levels of livestock intensity than large farms. Among the more carefully conducted studies is Surjit Sidhu's study of the adoption of modern wheat varieties in the Indian Punjab [55]. He shows that the MV wheat represented a neutral technological change with respect to farm scale: both small and large farms achieved approximately equal gains in efficiency. ${ }^{10}$

A study by Azam [1, p. 418] in Pakistan interprets the data from the Pakistani Punjab to indicate 'that, while the smaller farmers do face more severe constraints of irrigation water and credit, the difference in the severity of these constraints is not serious enough to have caused any significant differences in the yields obtained by the small farmers and the large farmes. ${ }^{11}$ Similar results have been reported for rice from the Philippines by Mangahas et al. [46], and from Indonesia by Soejono [58] .

Again, there are cases in which differential productivities were recorded. However, they seem to be the exception. For example, among the 32 villages throughout Asia covered by the IRRI-coördinated project, significant differences in rice yields per hectare between large and small farmers were recorded in only 8 villages $[31$, p. 96]

A major puzzle is why, in view of the evidence, planners and officials in developing countries and officials in national and international development assistance agencies remain skeptical about the efficiency of small farms. One reason may be that as a country develops and the opportunity cost of labour rises, the special efficiency advantage of small farms tends to disappear. It thus becomes natural to associate large farms with a highly developed national economy.

\section{Did the MV Technology Promote Mechanization?}

The popular perception that the MV technology stimulates the introduction of labour-displacing machinery has not been borne out by careful analysis. The data in Figure 3 indicate that increases in the adoption of tractors by large farmers began earlier than the introduction of MVs. Nor was there any indication that tractor adoption was accelerated by the dramatic diffusion of MVs from the late 1960s to the early 1970 s.

Much of the growth in the use of tractors in South and Southeast Asia can be attributed to distortions in the price of capital by such means as overvalued exchange

${ }^{10}$ Sidhu [55, p. 746$]$ concludes, “(1) that small and large wheat producing farms have equal relative economic efficiency and equal relative price efficiency and (2) that tractor-operat ed and non-tractor operated wheat producing farms have equal relative economic efficiency an equal relative price efficiency. .. This implies that he equal relative economic efficiency and equal relative price efficiency.... This implies that these farms also have equal technical efficien. cy.'

For a more recent assessment, see Chaudhry [12]. Also the exchange between Chaudhry 
rates and concessional credits from national governments and international lending agencies $[5 ; 44 ; 17]$. Also, the ease of supervising the operation of one tractorcum-operator relative to that of supervising a large number of labourers and bullock teams seems to have worked as a strong inducement to tractorization on large farms [8]. This factor should have been especially serious where regulation of land rent and tenure arrangements depressed the incentive of large land-owners to rent out their holdings in small operational units.

\section{Did the MV Technology Reduce Labour Employment and Earnings?}

An extensive review of the literature by Bartsch [6] indicates that the introduction of MVs into traditional wheat and rice producion systems has typically resulted in substantial increases in annual labour utilization per unit of cropped area, and in some cases, in higher cropping intensity. ${ }^{12}$ Similarly, data assembled by Barker and Cordova [4] from various areas in Asia show that labour input per hectare of rice cropped area was higher for MVs than for traditional varieties by $10-50$ percent.

Sidhu's econometric investigation [54] indicates a very substantial shift to the right of the labour demand function on wheat farms in Indian Punjab as a result of the introduction of MVs. Similar results were obtained by both Rao [51] and Staub [60].

Increases in labour use associated with MVs were often realized despite the concurrent progress in mechanization. The data on labour use in rice production from Laguna province in the Philippines, as presented in Table 3, are typical of this process. This province experienced rapid diffusion of both modern rice varieties and tractors. Labour application for land preparation was reduced by tractorization, but the reduction was more than compensated for by increases in labour use for weeding and other crop care.

The econometric test by Sidhu [55] on Punjab wheat production shows that the new technology was neutral with respect to factor use, implying that labour's income rises proportionally with the incomes accruing to land and capital. A similar study by Ranade and Herdt [50] on rice in the Philippines suggests that the MV technology is biased in the land-saving direction.

However, several other studies show that the labour share declined and the land share of income increased over the period of MV diffusion. Jha's data [33] indicate

${ }^{12}$ The Bartsch analysis [6] indicates that in wheat production, under a wide range of technologies ranging from primary dependence on human labour to fully mechanized production, the shift from traditional varieties to high-yielding MVs led to increased labour inputs per hectare. When this shift to MV technology was accompanied by a simultaneous shift to a fully mechanized technology, labour input per hectare declined. In all cases output per unit of labour input rose.
Table 3.

Percent of Farms Adopting MV and Tractors and Use of Labour Man-days per Hectare for Rice Production in Laguna, Philippines: 1966-75 Wet Seasons

\begin{tabular}{|c|c|c|c|}
\hline & 1966 & 1970 & 1975 \\
\hline MV adopters $(\% \text { of farms })^{a}$ & 0 & 76 & 94 \\
\hline Tractor adopters (\% of farms) ${ }^{a}$ & 26 & 71 & 90 \\
\hline Average paddy yield (t/ha) & 2.5 & 3.4 & 3.5 \\
\hline \multicolumn{4}{|l|}{ Labour input (man-days/ha) } \\
\hline Land preparation & 18.7 & 11.1 & 9.0 \\
\hline Transplanting & 10.2 & 10.2 & 10.9 \\
\hline Weeding & 13.8 & 17.8 & 31.3 \\
\hline Other pre-harvest operations & 9.4 & 14.8 & 20.2 \\
\hline Harvesting and threshing & 31.6 & 33.6 & 31.6 \\
\hline Post-harvest operations & 4.4 & 5.4 & 3.4 \\
\hline Total & 88.1 & 92.9 & 106.4 \\
\hline
\end{tabular}

Source: R. Barker and V.G. Cordova [4, pp. 120 \& 127].

${ }^{\mathrm{a}}$ Averages for wet and dry seasons.

that the share of land rose in India between 1960-61 and 1970-71. Data assembled by Mellor and Lele [47] indicate that a disproportionately small percentage of the increased output due to MV adoption was allocated to labour.

The data on relative shifts in factor shares cannot be interpreted, without further analysis, to indicate that land-owners have gained relative to tenants and labourers from the adoption of the higher-yielding grain varieties. Considerable confusion has resulted from neglect of the fact that while the income share of land increased, as Jha's data clearly show, not only did technology change but labour supply increased. As the model in Figure 2 illustrates, if the labour supply increases faster than labour demand, it is possible for the factor share of land to rise even if the technological change itself was biased in the land-saving and labour-using
direction.

Most of the data that indicated a rise in the share of land, such as that presented by Mellor and Lele [47], were obtained during the initial stages of MV adoption. MVs accounted for only a small percentage of the area cultivated and of output. There was, therefore, only a modest shift in aggregate wheat or rice production or in aggregate factor demand. In such a situation, early adopters were able to capture large excess profits (Schumpeterian entrepreneurial profit) from the use of more efficient technology without forcing down product prices or bidding up factor prices appreciably. However, as the technology diffuses widely, innovators' excess 
profit will be lost as product and factor prices move towards a new equilibrium. In the long run, the relative share of labour will return to the same level as before the introduction of MV if MV represents a neutral technological change. It will become larger if the technology is biased in the land-saving and labour-using direction. This sequence is supported by a number of studies. For example, a study by Bardhan [3] in North India at the beginning of MV diffusion indicated no significant effect of the 'green revolution' on the demand for rural labour. However, an analysis by Deepak Lal [40] in the same region for a later period shows clearly that as MV use diffused more widely the net effect of the resulting increase in labour demand was a significant rise in the real wage rates in the Punjab and other parts of North India at a time when real wage rates were constant or declining in other parts of India where MV diffusion was limited.

How do we interpret the critical assessments of the income distribution effects of the green revolution in view of the findings reported in this section? First, it is apparent that many of the critical assessments that were made during the initial years of the green revolution were based on limited data and, in some cases, an excessively casual approach to analysis of the data that were available. Secondly, there was a general failure to understand that the impact of a technical change on income distribution is a function of both the character of the technology and the economic and institutional environment into which it was introduced. There is as yet no evidence that the HYV technology is heavily biased against labour and there is substantial evidence that in most areas where it has been adopted it has increased the demand for labour. ${ }^{13}$ And there is a growing body of evidence that the impact on production and on labour demand has spilled over into a positive impact on the quality of life in rural villages.

In his Punjab village study, for example, Leaf [42, p. 268] notes that farmers now "grow more per hectare ... and more per capita overall. As measured by food, medical care, educational facilities, and housing, there have been substantial improvements in general welfare .... the gains have gone at least as much to the poorer villages as to the wealthier . . . . the poorer families are remaining in the village and finding work and improving living conditions .... they are able to send increasing numbers of their children to school .... The wealthier families who have already invested more in education . . . . are sending members out . . . to white-collar and other types of service employment ...."14 In addition, the MV technology and the increased agricultural income resulting from its adoption have had the important

${ }^{13} \mathrm{~A}$ limitation of most of the studies that are currently available is that they tend to employ a microeconomic partial-equilibrium analysis. A series of sector-level general-equilibrium econometric studies is now under way which should provide more definitive results than are now available. For a preliminary report, see Evenson $[18 ; 19]$.

${ }^{14}$ See also Blyn $[10]$. effect of creating non-agricultural employment opportunities through increased demand for non-agricultural goods and services by the agricultural sector $[47 ; 43]$.

\section{TOWARDS GROWTH WITH EQUITY}

Our examination of the relationship between technological change and income distribution suggests that the commonly assumed trade-off between growth and equity appears to be more relevant as an issue for ideological debate than as a description of contemporary development experience. The development and diffusion of new technology that is consistent with factor endowments are a necessary condition for agricultural output and productivity growth. The new technologies that meet the test of efficiency and productivity are also the technologies most likely to advance equity objectives.

In the agriculture of developing countries, in which land is becoming increasingly scarce and expensive relative to labour as population pressure increases against land resources, the development of biological and chemical technologies is the most efficient way of promoting agricultural growth. Technological progress of this type tends to make small-scale operations more efficient. It thereby induces an agrarian structure characterized by a unimodal distribution of small family farms rather than a bimodal distribution consisting of large commercial farmers and large numbers of landless or near-landless labourers. Moreover, because such technological progress tends to be generally biased, or at least neutral, towards labour use, it helps to counteract the effect of population pressure on land rent and wages.

Technological progress, by definition, results in a downward shift in the cost curve and a shift to the right in the product supply curve. In developed market economies, where producers sell a large share of their output in the market, the shift to the right in supply, when confronted with the inelastic demand, causes a disproportionately large fall in product prices. The effect is to transfer the gains from technical change from producers to consumers. However, when technological progress occurs in a semi-subsistence economy where producers consume a large fraction of their produce, a significant portion of consumers' surplus remains with producers. The gain in consumers' surplus may more than compensate for the loss in producers' surplus. The producers' gain, in the form of consumers' surplus, is proportionately larger for small farmers who consume a larger share of their production than large farmers. Thus, while large commercial farmers may lose from the decline in product prices, small subsistence farmers are more likely to share the benefit from technological progress.

The development of more productive biological and chemical technologies capable of offsetting the effect of growing population pressure appears to be a necessary condition for the simultaneous achievement of both growth and equity in developing countries today. If developing countries fail to achieve sufficiently rapid 
technological progress, greater poverty and greater inequity in rural areas will be the inevitable result. As the growth of population presses against limited land resources under existing technology, the cultivation frontier is forced onto more marginal land. More labour must be applied per unit of cultivated land with the result that the cost of food production increases and food prices rise. The long-run effect will be the reduction of wages to a subsistence level with the small surpluses that are available captured by landlords in the form of land rent.

It is clear that a necessary condition for escape from the Ricardian trap is landsaving and labour-using technical change. However, even if such technology is developed, its contributions to growth and equity will be small if it does not achieve rapid diffusion. If it is confined to a few regions or if adoption is limited to a few large farmers in each village, the aggregate product supply and the aggregate labour demand will not shift appreciably. There will be only a limited impact on product prices and wage rates. The adopters will continue to enjoy innovators' excess profits, or bid the profits into higher land prices, but the landless population will not be able to share in the benefits of technological progress in the form of higher wages and lower food prices.

The MV technology, enthusiastically heralded as the 'green revolution', has often been regarded as a source of inequity in rural incomes. This view is generally inconsistent with the green revolution experience. The MV technology diffused rapidly among farmers irrespective of farm size and land tenure in the areas where the technology was superior to traditional technology. There are, however, numerous cases where adoption by small or poor farmers lagged significantly behind the large or wealthy farmers in the adoption of MV and related inputs. Such cases are largely a reflection of institutional rather than technical bias. In such situations, institutional reforms are necessary in order to partition equitably the new income streams generated by an appropriate technology.

Grabowski [26, pp. 180-181] has listed the necessary reforms:

Research activities must be directed at developing new seeds for the majority of farmers who lack irrigation. Research activities need to be oriented toward improving cultivation practices and irrigation techniques in order to increase cropping intensity. Credit must be made available to allow farmers with small farms to irrigate their land and thus increase their cropping intensities ..... Larger farmers' privileged access to machinery must be eliminated ..... All of these require an increase in the power and influence of farmers with small farms, relative to those with large farms, on government decisions concerning agricultural research and credit priorities. This could possibly be accomplished through land reforms or, a less radical solution, the organization of small farmers into groups which could put pressure on government agencies to recognize and respond to the interest of small farmers.

These reforms are clearly desirable. But what are the conditions that make them economically and politically viable? It is a common observation that in a society characterized by extreme bias in economic and political resources it is difficult to design institutional reforms that are biased against those who possess substantia to design institutional and political resources. A disproportionate share of institutional credit and subsidized inputs will, in such situations, be directed into the hands of the larger farmers. Land reform programmes are likely to lead to eviction of tenants and conversion of land use from labour-intensive crops such as rice to extensive crops such as coconuts. It is exceedingly difficult to design institutions that are neutral or biased towards the poor in a society characterized by extreme inequality in economic resources and political power.

A relevent question, given the extreme inequality in wealth and power in many developing countries, is whether the development of the 'green revolution' technology should be withheld because of its possible adverse effect on income distribution. Even the most severe critics of the green revolution technology have seldom been willing to advocate such a policy. MV technology has been diffusing in Asia with sufficient speed to shift the product demand and the labour supply significantly There have been substantial gains to both producers and consumers. In the absence of the new technology, many developing countries would have moved several steps closer to the Ricardian trap of economic stagnation and greater stress over the distribution of income. The conclusion that should be drawn from this experience is not that growth has been 'immiserizing' but that stagnation has been [56]

A further reason for encouraging the development and diffusion of new bio logical and chemical technologies, even in societies characterized by inequitable distribution of economic and political resources, is that the new income streams generated by technical change represent a powerful source of demand for institutional change. The early critics of the MV technologies tended to emphasize the regressive nature of these institutional changes. But it now seems clear that in many countries the potential gains from the new technology have generated effective demand for the reform of factor and product market institutions. The gains from the new technology can be fully realized only if land tenure, water management, and credit institutions perform effectively. Markets for the inputs in which the new technology is embodied - the seeds, fertilizer, and pesticides - must perform efficiently. Prod uct markets in which either the domestic or international terms of trade are biased against food or export commodity producers fail to generate the potential gains from new technology. In a society in which marketable surpluses are small and tech nology is static, there are few gains, either to producers or consumers, from the reform of market institutions. But when rapid growth of production, and of productivity, becomes possible, the gains become larger and the incentives that act to induce institutional reforms become more powerful.

We do not argue, of course, that the dialectical interaction between technical and institutional innovation always functions to enhance both growth and equity Kuznets and others have documented the tendency for income distribution to worsen during the initial stages of development $[39 ; 2]$. The potential gains from 
technical change set in motion both private and bureaucratic efforts to capture the gains from technical change in the form of institutional rents rather than allowing the market to partition the gains among factor owners and consumers. The possibilities for bias in institutional innovations are greatest in societies in which the distribution of economic and political resources is highly unequal.

These institutional biases may in turn induce further bias in the direction of technical change. In a bimodal rural society with a few large estate owners and large numbers of landless or near-landless labourers, for example, the factor prices that are taken into consideration in the decision-making of the estate owners may be very different from social opportunity costs. For the estate owners, unit labour costs may be substantially higher than market wage rates because a significant cost is involved in supervising a large number of hired labourers. They may also have access to capital at a price cheaper than its social opportunity cost through such means as subsidized credits and overvalued exchange rates. In such situations, the research system may respond to the demand of the larger farmers by producing technologies biased towards a labour-saving and capital-using direction even if a socially optimum direction of technological change may be labour-using and land-and capital-saving. Those technologies, in turn, may strengthen the existing social system by making large-scale farms relatively more efficient. ${ }^{15}$

We should emphasize, at this point, the limited impact that even the most appropriate technical changes have on the growth and distribution of income in rural areas when unaccompanied by effective development efforts in other sectors. If the rate of productivity growth in agriculture exceeds the rate of growth of the agricultural labour force, it creates an opportunity for growth in per capita income in rural areas. And if the direction of technical change is consistent with resource endowments, and if the distribution of economic and political resources is not too badly skewed, the benefits of productivity growth may be broadly diffused within rural communities and between the rural and urban sectors. But rapid growth in rura incomes and in returns to labour is also dependent on rapid growth in non-agricultural employment opportunities and on effective inter-sector labour markets. We do not, therefore, argue that the rapid and appropriate growth in agricultural productivity represents a solution to either the income level or income distribution problem in rural areas. We do insist that it is a necessary condition.

\section{REFERENCES}

1. Azam, K.M. "The Future of the Green Revolution in West Pakistan: A Choice of Strategy". International Journal of Agrarian Affairs. Vol. 5. 1973. pp. 404-29.

${ }^{15}$ See the Argentine example discussed in the work of Alain de Janvry [16].
2. Bacha, E.L. "The Kuznets Curve and Beyond: Growth and Changes in Inequalities". In E. Malinvaud (ed.), Economic Growth and Resources. Vol. I. New York: St. Martin's Press. 1979. pp. 52-71.

3. Bardhan, P.K. "Green Revolution and Agricultural Laborers". Economic and Political Weekly. Vol. 5. 1970. pp. 1239-46.

4. Barker, R., and V.G. Cordova. "Labour Utilization in Rice Production" In R. Barker and Y. Hayami (eds.), Economic Consequences of the New Rice Technology. Los Banos, Philippines: International Rice Research Institute. 1978. pp. 113-36.

5. Barker, R., W.H. Meyers, C. Cristostomo, and B. Duff. "Employment and Technological Change in Philippine Agriculture". International Labour Review. Vol. 106. 1972. pp. 111-39.

6. Bartsch, W.H. Employment and Technology Choice in Asian Agriculture New York: Praeger Publishers. 1977.

7. Berry, R.A., and W.R. Cline. Agrarian Structure and Productivity in Develop ing Countries. Baltimore: Johns Hopkins University Press. 1979.

8. Binswanger, H.P. The Economics of Tractors in South Asia. New York Agricultural Development Council; and Hyderabad, India: International Crops Research Institute for the Semi-Arid Tropics. 1978.

9. Binswanger, H.P., V.W. Ruttan, et al. Induced Innovation: Technology, Institutions and Development. Baltimore: Johns Hopkins University Press. 1978.

10. Blyn, G. "The Green Revolution Revisited". Economic Development and Cultural Change. Vol. 31. 1983. pp. 705-25.

11. Chang. T. "Genetics and Evolution of the Green Revolution". In R. de Vicente (ed.), Replies from Biological Research: Proceedings of the Symposium on Biology and Ethics: Problems and Positive Results of Scientific Research in Genetics. Madrid: Consejo Superior de Investigaciones Cientificas. 1979. pp. 187-209.

12. Chaudhry, M.G. "The Green Revolution and Income Inequality: Some Empirical Evidence from Rural Pakistan”. Ph.D. dissertation, University of Wisconsin, Madison. 1980.

13. Chaudhry, M.G. "Green Revolution and the Redistribution of Rural Incomes: Pakistan's Experience”. Pakistan Development Review. Vol. 21. 1982. pp. 173-205.

14. Chaudhry, M.G. "Green Revolution and Redistribution of Rural Incomes: Pakistan's Experience - A Reply”. Pakistan Development Review. Vol. 22. 1983. pp. 117-24.

15. Cleaver, H. "The Contradictions of the Green Revolution". American Economic Review. Vol. 62. 1972. pp. 177-88. 
16. de Janvry, A. "A Socioeconomic Model of Induced Innovation for Argentine Agricultural Development". Quarterly Journal of Economics. Vol. 87. 1973. pp. 410-35.

17. Duff, B. "Mechanization and Use of Modern Varieties". In R. Barker and Y. Hayami (eds.), Economic Consequences of the New Rice Technology. Los Banos, Philippines: International Rice Research Institute. 1978. pp. $145-64$.

18. Evenson, R. E. "Economics of Agricultural Growth: The Case of Northern India". In K.C. Nobe and R.K. Sampath (eds.), Issues in Third World Development. Boulder, Colo.: Westview Press. 1983. pp. 145-91.

19. Evenson, R.E. "Population Growth and Agricultural Development in North India". Paper presented at Conference on Recent Population Trends in Southwest Asia, New Delhi, Feb. 2-8, 1983.

20. Falcon, W.P. "The Green Revolution: Generations of Problems". American Journal of Agricultural Economics. Vol. 52. 1970. pp. 698-710.

21. Fatemi, A.M.S. "The Green Revolution: An Appraisal". Monthly Review. Vol. 24. 1972. pp. 112-20.

22. Frankel, F.R. India's Green Revolution: Economic Gains and Political Costs. Princeton, N.J.: Princeton University Press. 1971.

23. Gerhart, J. The Diffusion of Hybrid Maize in Western Kenya. Mexico, D.F.: Centro International de Mejoramiento de Maiz y Trigo. 1975.

24. Ghatak, S. (with D. Deadman and C. Eadie). Technology Transfer to Developing Countries: The Case of the Fertilizer Industry. Greenwich, Conn.: JAI Press. 1981.

25. Goldman, R.H., and L. Squire. "Technical Change, Labor Use, and Income Distribution in the Muda Irrigation Project". Economic Development and Cultural Change. Vol. 30. 1982. pp. 753-75.

26. Grabowski, R. "Induced Innovation, Green Revolution, and Income Distribution: Reply". Economic Development and Cultural Change. Vol. 30. 1981. pp. 177-81.

27. Griffin, K. The Political Economy of Agrarian Change: An Essay on the Green Revolution, 2nd. ed. London: Macmillan Co. 1979.

28. Hayami, Y. "Elements of Induced Innovation: A Historical Perspective for the Green Revolution". Explorations in Economic History. Vol. 8. 1971. pp. 445-72.

29. Hayami, Y. "Induced Innovation, Green Revolution, and Income Distribution: Comment". Economic Development and Cultural Change. Vol. 30. 1981. pp. 169-76.

30. Hayami, Y., and M. Kikuchi. Asian Village Economy at the Crossroads. Tokyo: University of Tokyo Press; and Baltimore: Johns Hopkins University Press. 1981 and 1982.
31. International Rice Research Institute (IRRI). Interpretive Analysis of Selected Papers from Changes in Rice Farming in Selected Areas of Asia. Los Banos, Philippines: IRRI. 1978.

32. Jennings, P.R. "Plant Type as a Rice Breeding Objective". Crop Science. Vol. 4. 1964. pp. 13-15.

33. Jha, D. "Agricultural Growth, Technology and Equity". Indian Journal of Agricultural Economics. Vol. 29. 1974. pp. 207-16.

34. Johnston, B.F., and J. Cownie. "The Seed-Fertilizer Revolution and Labor Force Absorption". American Economic Review. Vol. 59. 1969. pp. $569-82$.

35. Kawagoe, T., and Y. Hayami. "The Production Structure of World Agriculture: An Intercountry Corss-Section Analysis". The Developing Economies. Vol. 21. 1983. pp. 189-206.

36. Khan, M.H. The Economics of the Green Revolution in Pakistan. New York: Praeger Publishers. 1975.

37. Khan, M.H. "Green Revolution and Redistribution of Rural Incomes: Pakistan's Experience - A comment". Pakistan Development Review. Vol. 22. 1983. pp. 47-56.

38. Krishna, R. "Measurement of the Direct and Indirect Employment Effects of Agricultural Growth with Technological Changes". In E.O. Heady and L.R. Whiting (eds.), Externalities in the Transformation of Agriculture. Ames: Iowa State University Press. 1975. pp. 305-27.

39. Kuznets, S. "Economic Growth and Income Inequality". The American Economic Review. Vol. 45. 1955. pp. 1-28.

40. Lal, D. "Agricultural Growth, Real Wages, and the Rural Poor in India". Economic and Political Weekly. Vol. 11. 1976. pp. A47-61.

41. Lappe, F.M., and J. Collins. Food First: Beyond the Myth of Scarcity, rev. ed. New York: Ballantine. 1979. pp. 121-68.

42. Leaf, M.J. "The Green Revolution and Cultural Change in a Punjab Village, 1965-1978”. Economic Development and Cultural Change. Vol. 31 1983. pp. $227-70$.

43. Lele, U., and J.W. Mellor. "Technological Change, Distributive Bias and Labor Transfer in a Two Sector Economy". Oxford Economic Papers. Vol. 33. 1981. pp. 426-41.

44. McInerney, J. P., and G. F. Donaldson. The Consequences of Farm Tractors in Pakistan. World Bank Staff Working Paper No. 210. Washington, D.C.: World Bank. 1974.

45. Mangahas, M. "Economic Aspects of Agrarian Reform under the New Society". The Philippine Review of Business and Economics. Vol. 11. 1974. pp.
175-87. 
46. Mangahas, M., V. A. Miralao, R. P. de los Reyes, with N. de leon. Tenants, Lessees, Owners: Welfare Implications of Tenure Change. Quezon City: Ateneo de Manila University Press. 1976.

47. Mellor, J. W., and U. J. Lele. "Growth Linkages with the New Foodgrain Technologies”. Indian Journal of Agricultural Economics. Vol. 28. 1973. pp. 35-55.

48. Palmer, I. The New Rice in Asia: Conclusions from Four Country Studies. Geneva: United Nations Research Institute for Social Development. 1976.

49. Parthasarathy, G. "West Godavari, Andhra Pradesh". In Changes in Rice Farming in Selected Areas of Asia. Los Banos, Philippines: IRRI. 1974. pp. 43-70.

50. Ranade, C. G., and R. W. Herdt. "Shares of Farm Earnings from Rice Production". In R. Barker and Y. Hayami (eds.), Economic Consequences of the New Rice Technology. Los Banos, Philippines: IRRI. 1978. pp. 87-104.

51. Rao, C. H. H. Technological Change and Distribution of Gains in Indian Agriculture. Delhi: Macmillan Company of India. 1975.

52. Ruttan, V. W. "The Green Revolution: Seven Generalizations". International Development Review. Vol. 19. 1977. pp. 16-23.

53. Sen, B. The Green Revolution in India: A Perspective. New Delhi: Wiley Eastern. 1974.

54. Sidhu, S. S. "Economics of Technical Change in Wheat Production in the Indian Punjab”. American Journal of Agricultural Economics. Vol. 56. 1974. pp. 217-26.

55. Sidhu, S. S. "Relative Efficiency in Wheat Production in the Indian Punjab" The American Economic Review. Vol. 64. 1974. pp. 742-51.

56. Singh, I. "The Landless Poor in South Asia". In A. Maunder and K. Ohkawa (eds.), Growth and Equity in Agricultural Development, Proceedings, Eighteenth International Conference of Agircultural Economists, Jakarta, Indonesia, Aug. 24-Sept. 2, 1982. Aldershot, Hampshire, England: Gower Publishing Co., Ltd. 1983. pp. 379-400.

57. Singh, I. Small Farmers and the Landless in South Asia. Washington, D.C.: Johns Hopkins University Press; in press.

58. Soejono, I. "Growth and Distributional Changes of Paddy Farm Income in Central Java, 1968-1974”. Ph.D. diss., Iowa State University, Ames, Iowa. 1976.

59. Soejono, I. "Growth and Distributional Changes in Paddy Farm Income in Central Java”. Prisma (Indonesian Journal of Social and Economic Affairs). No. 3. 1976. pp. 26-32.
60. Staub, W. Agricultural Development and Farm Employment in India. Washington, D.C. U.S. Dept. of Agriculture, Economic Research Service, Foreign Agricultural Economic Report No. 84. 1973.

61. Swaminathan, M. S. "Rice". Scientific American. Vol. 250. 1984. pp. 80-93.

62. Wharton, C. R. "The Green Revolution: Cornucopia or Pandora's Box?" Foreign Affairs. Vol. 47. 1969. pp. 464-76. 